\title{
Diversity and host preferences of ferns and lycopods epiphytes on palm trees
}

\author{
TITIEN NGATINEM PRAPTOSUWIRYO", SUMANTO, RIA CAHYANINGSIH \\ Research Center for Plant Conservation and Botanic Gardens (Bogor Botanic Gardens), Indonesian Institute of Sciences. Jl. Ir. H. Juanda No. 13, Bogor \\ 16022, West Java, Indonesia. Tel.: +62-251-8322187. Fax.: +62-251-8322187, "email: tienpferns@ gmail.com; tienpferns@yahoo.com
}

Manuscript received: 2 September 2019. Revision accepted: 26 November 2019.

\begin{abstract}
Praptosuwiryo TN, Sumanto, Cahyaningsih. 2019. Diversity and host preferences of ferns and lycopods epiphytes on palm trees. Biodiversitas 20: 3731-3740. Epiphytic ferns contribute importantly to the global biodiversity of tropical rain forests. However, our knowledge of the ecology of epiphytic ferns is phenomenally still limited. Most studies on the ecology, floristic and diversity of epiphytic ferns and lycopods were reported outside of Malesian region. This study aimed: (i) to figure out the diversity of ferns and lycopods on palm trees of the lowland areas by analyzing its species richness and floristic composition, and (ii) to determine the host preferences of epiphytic ferns on palm trees. Twenty-eight phorophyte species belonging to 17 genera of palm trees, growing at Bogor Botanic Gardens, were observed. Trunk of palm trees was divided into three zones (basal, middle and upper). Individual numbers for each species of epiphytic fern growing on each zone were recorded. Epiphytic fern species which were most commonly found were analyzed statistically to determine their preference for the host trees. A total of 16 species of epiphytic ferns and lycopods were recorded. The greatest richness of species occurred in Polypodiaceae (50\%). Habitual true epiphyte was the predominant ecological category, representing $75 \%$ of the species. Caryota no Becc. hosted the greatest number of ferns and lycopods 8 species) while Attalea insignis (Mart.) Drude hosted the fewest (2 species). Individual numbers of six epiphytic fern species were significantly affected by palm trees species, namely Belvisia callifolia (Christ) Copel., Pyrrosia lanceolata (L.) Farwell, Pyrrosia piloselloides (L.) M.G. Price, Davallia denticulata (Burm.) Mett., Nephrolepis biserrata (Sw.) Schott, Vittaria ensiformis Sw. Individual numbers of five epiphytic fern species were significantly affected by zone of the host plant. Nephrolepis biserrata tends to grow well in the upper zone. Pyrrosia lanceolata tends to be abundant in the middle zone. B. callifolia, D. denticulata, and V. ensiformis grow well and make dense populations in the basal zone.
\end{abstract}

Keywords: Fern epiphytes, floristic composition, host preference, species richness

\section{INTRODUCTION}

Ferns are vascular plants that produce spores and undergo an alternation of generations, with separate gametophyte and sporophyte generations that exist as freeliving plants. Lycopods are similar to ferns in this regard, but ferns are the sister group of the seed plants (gymnosperms plus angiosperms), whereas the lycopods are sister to all other vascular plants (ferns plus the seed plants) (Christenhusz and Chase 2014). Plants in the lycophyte and fern clades are all spore-bearing and because of this common feature their members have been lumped together historically under various terms, such as "pteridophytes" and "ferns and fern allies". Therefore, pteridophytes is paraphyletic assemblages of plants (Smith et al. 2008).

Ferns and lycophytes are distributed globally with a total of ca. 11,000 species (Smith et al. 2006) and they play very important roles at the ecosystem level in both temperate and tropical forests. Ferns have been shown to control the regeneration potential of forests throughout the world (George and Bazzaz 1999; Coomes et al. 2005). In tropical forests, basket-forming ferns can harbor more arthropod diversity in a single individual than occurs in the entire canopy of the fern's host tree (Ellwood and Foster 2004). Ferns can also be critical players in ecosystem establishment (Russell and Vitousek 1997). Ferns make up an important component of tropical and temperate floras and serve important functions in ecosystem processes in both the canopy (Hietz 1997) and forest floor habitats (Hill and Silander 2001). Ferns are particularly sensitive to air humidity and temperature and are therefore potentially useful as bio-indicators of climate change (Benzing 1998, Zotz and Bader 2009; Pouteau et al. 2016), these plants are used as a bioindicator of different types of forests (Zapfack et al. 1996; Salovaara et al. 2004). With the retention of the independent gametophyte, ferns also hold tremendous potential to teach us about the evolutionary ecology of early vascular plants (Watkins et al. 2007).

Epiphytes are plants that inhabit a discontinuous and three-dimensional landscape, directly in contact with the forest soil or not (Bennett 1986). Kress (1986) defined that epiphytes are vascular and non-vascular plants that live on other plants (i.e. phorophytes) such as trees for physical support; however, they do not gain nutrients or water supply directly from the host (Kress 1986). Epiphytes can be split into several distinctive groups i.e. according to (i) their timing during life cycle (holo-and hemi-epiphytes), (ii) their fidelity to bark (facultative, obligate and accidental epiphytes), (iii) their light requirements (sun-, shade-tolerance), (iv) their substrate exploitation preference (e.g. bole, twigs, branch) and (v) their nutritional mode 
(Benzing 2004; Nieder et al. 2001). Epiphytes consist of several groups of algae, bryophytes, mosses, ferns, and spermatophytes, which attach from the base of the stem to the end of the branch of trees. The distribution, composition, and abundance of epiphytes in the host tree are closely related with the bark characteristics, the slope of the stem, the branching and twig systems, canopy shape, water availability, temperature, humidity and light intensity (Grubb et al. 1963; Steenis 1972; Benzing 1981, 1984; Partomihardjo and Kartawinata 1984; Partomihardjo et al. 2004).

Epiphytes are considered as an important component of global plant diversity. They represent c. $10 \%$ of the world's vascular plant species (Gentry and Dodson 1987; Nieder et al. 2001). These organisms occur in abundance within the tropical rainforest, in fact up to 25,000 species of vascular epiphytes alone that occur mainly in the tropics (Zotz and Hietz 2001).

Epiphytes are also important for biogeochemical processes. Some epiphytes create favorable microsites for nitrogen-fixing free-living bacteria (Brighigna et al. 1992). Epiphytes also increase retention of water derived from precipitation within the forest (Veneklaas and Van Ek 1990; Veneklaas et al. 1990). Due to their high growth efficiency, including leaf production and root growth, epiphytes make greater contributions to primary productivity, litterfall and nutrient cycling (Putz 1983; Hegarty 1991).

Epiphytes are also important as refuges for reptiles and amphibians in the canopy of tropical rainforests (Huang and Pike 2011; Scheffers et al. 2014). Bird's nest ferns were shown to provide cool, moist microhabitats for Platymantis arboreal frogs within the relatively hot and dry canopy (Scheffers et al. 2014). Bats have been shown to use bird's nest ferns as a roost (Tan et al. 1999). Donald et al. (2017) demonstrate the importance of epiphytes in providing a resource for reptile populations in the rainforest canopy; bird's nest ferns are important for arboreal skinks and geckos as a valuable resource.

Epiphytic ferns make up a conspicuous component of tropical wet forest regions around the world. Epiphytic fern species contributes to higher phytodiversity in vertical space in the tropical rain forest (Page 1979). For example, in Costa Rica, $70 \%$ of the entire pteridoflora is epiphytic, while at La Selva Biological Station in northeastern Costa Rica epiphytic ferns comprise $42 \%$ of this lowland forest flora (Grayum and Churchill 1987). Pteridophytes represented over $25 \%$ of the epiphytic flora the Cameroonian semi-deciduous rain forest (Zapfack et al. 1996).

Although we have some knowledge of the role of epiphytic ferns in forests, however, our knowledge of the ecology of the epiphytic ferns is phenomenally still limited. Moreover, most studies on the ecology, floristic and diversity of epiphytic ferns and fern allies were reported outside of Malesian region (see Hooper and Haufler 1997; Roberts et al. 2005; Schmitt and Windisch 2010; Schneider and Schmitt 2011). Research work dealing with the ecology of epiphytic ferns in Malesian region is only few reported. However, information on the epiphytes is required in order to develop potential conservation and management strategies in a lowland tropical forest in the Malesian region.

There are a few of works on the documentation of ferns epiphytic flora growing on palm trees, see Sofiyanti (2013), Harmida et al. (2018), Adeleye et al. (2017), Prastyo et al. (2015), Zotz and Volrath (2003), and Sato et al. (1996). Most of these studies were focused on the diversity of epiphytic ferns on oil palm (Elaeis guineensis Jacq.) plantation (see Sato et al. 1996, Prastyo et al. 2015; Harmida et al. 2018). This research was conducted to fill out the lack of data on the diversity of epiphytic ferns in the Malesian region. We emphasized the study dealing with the epiphytic ferns and lycopods on palm trees in tropical lowland forests. We chose Bogor Botanic Gardens as representative site of lowland tropical areas to study the diversity and ecology of ferns and lycopods epiphytes growing on the palm trees. The objectives of this study were: 1) to figure out the diversity of ferns on palm trees on the lowland areas by analyzing its species richness and floristic composition, and (2) to determine the host preferences of epiphytic ferns on palm trees. This study will provide baseline information that could guide conservation and management of epiphyte communities on lowland tropical forests.

\section{MATERIALS AND METHODS}

Study site. This study was performed at the Bogor Botanical Gardens (Figure 1), from March 2012 to November 2014. Bogor Botanic Gardens is one of the oldest botanic gardens in the world. It was established on May $18^{\text {th }}$, 1817 , by Dr. C.G.C. Reindwardt. This old age allowing this botanical gardens providing shelter for many species of wild ferns and lycopods, including epiphytic ferns growing on palm trees and other trees of flowering plant collections.

The BBG has located about $60 \mathrm{~km}$ south of the capital city Jakarta, Indonesia. It is situated in the city center of Bogor and covering an area 87 hectares at about $215-250 \mathrm{~m}$ above sea level. Geographically, BBG is located between $106^{\circ} 47^{\prime} 40^{\prime \prime}-106^{\circ} 48$ ' $10^{\prime \prime} \mathrm{E}$ and $6^{\circ} 25^{\prime} 40^{\prime \prime}-6^{\circ} 36^{\prime} 20^{\prime \prime} \mathrm{S}$ (Figure 1.). The slope of the BBG land leads to Ciliwung River that splitting the botanical gardens into two areas. The soil of BBG is latosols, with reddish-brown color, and the topography of the botanical gardens is relatively flat with a slope of 3-15\% and $16-31 \%$ near the river bank.

According to the Koppen climate classification (Köppen 1936), BBG belongs to climate group A, tropical humid climates or tropical rainy climate, which is characterized by high temperature, warm temperature throughout with mean value exceeding $27^{\circ} \mathrm{C}$, and abundant rainfall (annual average $250 \mathrm{~cm}$ ). More specifically, the BBG climate belongs to the Wet Tropical Climate group (Af) with an average temperature of $26^{\circ} \mathrm{C}$ in each month, the lowest temperature is $21.4^{\circ} \mathrm{C}$ and the highest temperature is $30.4^{\circ} \mathrm{C}$. The humidity of more than $70 \%$, and the monthly rainfall ranges from $250-330 \mathrm{~mm}$. The annual rainfall varies between $3000-5000 \mathrm{~mm}$, with more 
than 240 rainy days. The highest rainfall occurs in December and January.

Observations of epiphytic ferns. For recording the floristic composition of the epiphytic ferns and lycopods, we choose and observed 28 species of palm trees belonging to 17 genera, covered 33 individual phorophytes, which were having more than $10 \mathrm{~cm}$ dbh., namely (1) Aiphanes minima (Gaertn.) Burret, (2) Arenga engleri Becc., (3) Arenga microcarpa Becc., (4) Arenga undulatifolia Becc., (5) Attalea sp., (6) Attalea microcarpa (H. Karst.) Linden, (7) Calypthrocalyx spicatus (Lam.) Blume, (8) Caryota no Becc., (9) Corypha umbraculifera, (10) Corypha utan, (11). Caryota sp., (12) Corypha sp.2, 13. Elaeis guineensis Jacq., (14) Latania verschaffeltii Lem., (15) Saribus woodfordii (Ridl.) Bacon \& W.J.Baker, (16) Metroxylon sagu Rottb., (17) Attalea speciosa Mart.., (18) Phoenix farinifera Roxb., (19) Phoenix pusilla Gaertn. (20) Phoenix sp.1, (21) Phoenix sp.2, (22) Phoenix sp.3, (23) Pinanga insignis Becc., (24) Sabal palmetto (Walter) Lodd. ex Schult. \& Schult.f., (25) Sabal sp., (26) Satakentia liukiuensis (Hatus.) H.E. Moore, (27) Attalea insignis (Mart.) Drude and (28) Verschaffeltia splendida H.A. Wendl. These species are planted in 17 collection sites
(Fak) in the gardens (Fak II.J., Fak III.A., Fak V.I., Fak V.J., Fak V.K., Fak V.M., Fak V.L., Fak V.X.D, Fak VII.A., Fak VII.E., Fak XIII.A., Fak XII.A., Fak XII.E., Fak X.D., Fak XIII.L., Fak XIV.A., Fak XVII.L.).

Sampling methods for statistical analyses. Thirtythree living palm trees (Arecaceae) belonging to 22 species with epiphytic ferns and with were having at least $10 \mathrm{~cm}$ of diameter of breast height (DBH) which were chosen purposively. Trunk of palm trees was divided in to three zonas: (i) basal areas; (ii) middle areas and (iii) upper areas (Figure 2.). The total number of species and individual of epiphytic ferns were recorded for each zonation. We chose to sample only trees with epiphytic ferns because we wanted to assess variation in this community. The delimitation of individual for the epiphytic ferns with very long creeping rhizomes, such as in the genus Pyrrosia and Nephrolepis, are very difficult. Therefore we used individual concept sensu Sanford (1968) and Zotz and Büche (2000) for this genus, a group of rhizomes and fronds belonging to one species, which forms a clearly delimited patch, for species having very long creeping rhizomes.

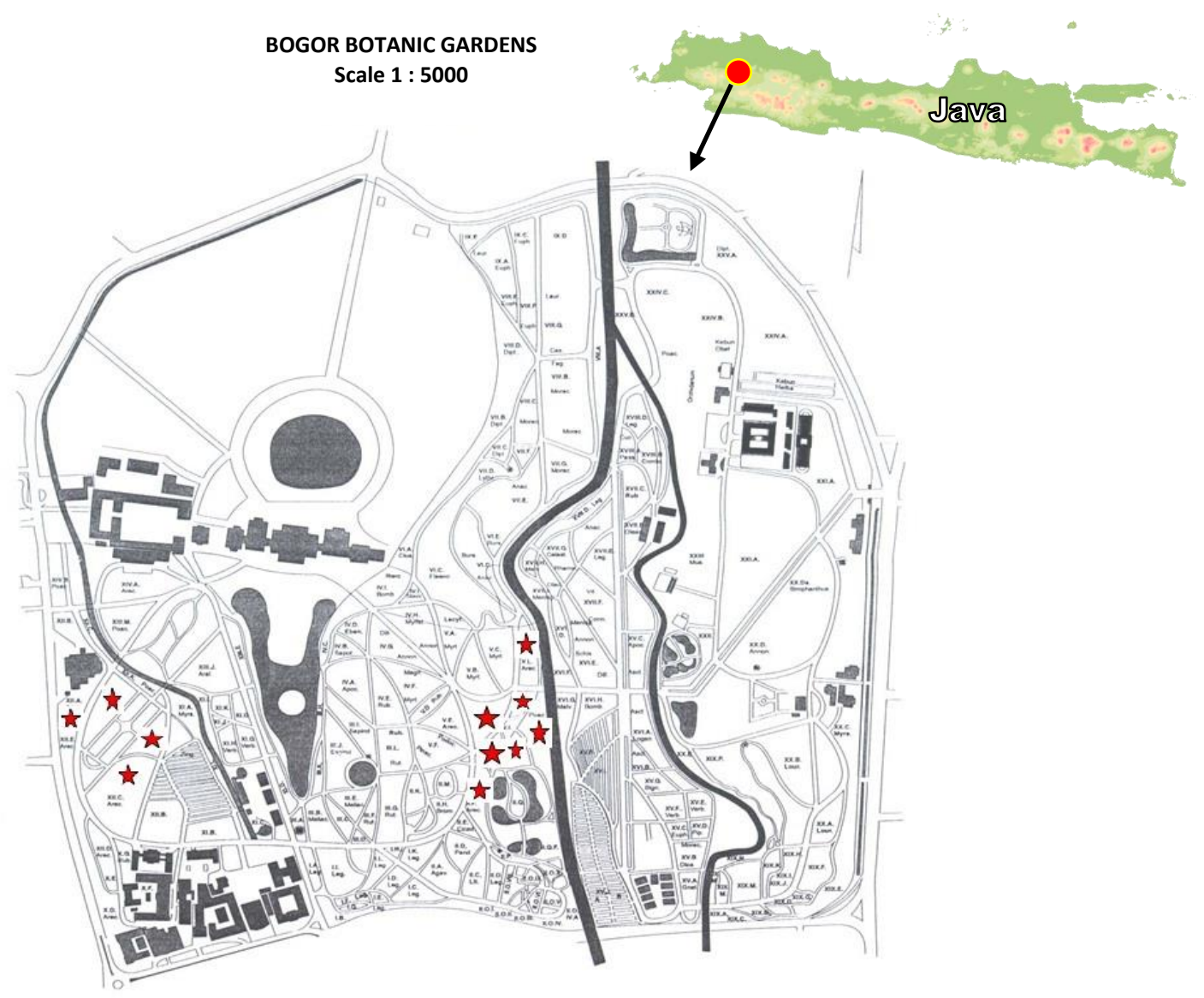

Figure 1. Map of Bogor Botanic Gardens, Indonesia. Stars indicate the location of the collection sites of the palm trees (Arecaceae) in which the observations of epiphytic ferns were performed 


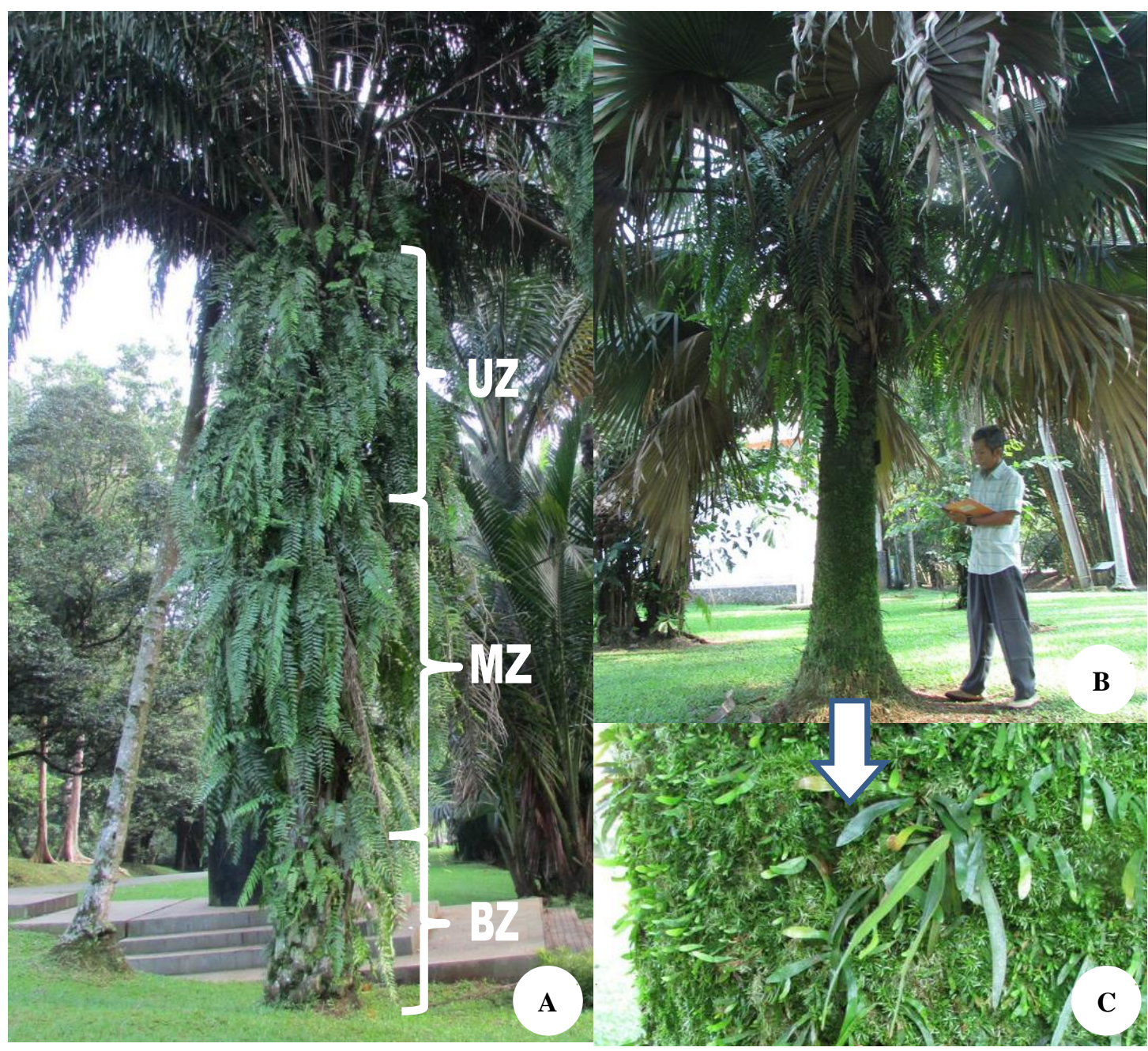

Figure 2. Recording species and individual numbers of epiphytic ferns growing on palm trees at Bogor Botanic Gardens, Indonesia. A. Elaeis guineensis Jacq. BZ = basal zone, $\mathrm{MZ}=$ middle zone, $\mathrm{UZ}=$ upper zone. B. Recording ferns epiphytic growing on Sabal palmetto (Walter) Lodd. ex Schult. \& Schult.f.. C. Vittaria ensiformis was growing well on the basal trunk of S. palmeto

Specimens were made according to the standard method for making herbarium specimens in ferns. Voucher specimens are deposited at the Herbarium of Bogor Botanic Gardens (BOHB). Species determinations were performed by consulting Backer and Posthumus 1939, Holttum (1966), Piggott and Piggot (1988), Hovenkamp et al. (1998), Hovenkamp and Ho (2012), and Zhang et al. (2013).

Measuring species diversity of ferns growing on palm trees at Bogor Botanic Gardens, West Java, Indonesia. Species richness and relative abundance are the two factors that are considered when measuring species diversity. Species richness refers to the number of species in an area. In this paper, species richness refers to the number of ferns species growing on a total of 33 individual phorophytes (palm trees). Species abundance refers to the total number of individuals per species. Relative species abundance is how common a fern species is relative to the other fern species in the total 33 individual phorophytes.
Statistical analysis for host preference of epiphytic fern species on palm trees. Host preference of epiphytic fern species on palm trees was analyzed using Proc GLM (General Linear Models) in Statistical Analysis Software (SAS) version 9.1.3. Eight species of epiphytic ferns, which were the most common on the palm trees, were selected, viz. Asplenium nidus, Belvisia callifolia, Pyrrosia lanceolata, Pyrrosia piloselloides, Davallia denticulate, Nephrolepis biserrata, Vittaria ensiformis, Goniophlebium percussum. Twenty-two species of palm trees, each represented by one individual plant, were selected. Palm trees (22 host trees) and three zones represented the treatments, meanwhile, the numbers of epiphytic fern species were observation object which arranged in Complete Randomized Design. The significant results were tested by the Tukey Test. 


\section{RESULTS AND DISCUSSION}

\section{Diversity and floristic composition of epiphytic ferns growing on the trunk of palm trees}

The floristic composition of ferns growing on palm trees is provided in Table 1 . We recorded 4406 individuals of 16 epiphytes species in total. They belong to 13 genera and 9 families. In species richness, Polypodiaceae was the greatest (50\%). Aspleniaceae, Davalliaceae, Gleicheniaceae, Lycopodiaceae, Nephrolepidaceae, Oleandraceae, Selaginellaceae, and Vittariaceae were each represented by a single species. Globally, high percentages of epiphytic plants among families containing over 50 epiphytic species are known on ferns of Polypodiaceae as 94\% (1029/1100) (Kress 1989).

\section{Relative species abundance of fern epiphytes growing on palm trees}

Species abundance can be figurated as percentage of the total of individuals of an epiphytic fern species of the total individual of all species occurred in a defined location or community (Tabel 1). There are eight common species growing on palm trees, namely Asplenium nidus, Belvisia callifolia, Davallia denticulata, Nephrolepis biserrata, Microsorum punctatum, Pyrrosia lanceolata, $P$. piloselloides, and Vittaria ensiformis. The most common taxon, $V$. ensiformis, which is widespread on the Tropics of the Old World, occurred on 13 palm trees and with 2451 individuals.

Four species of ferns can be considered to be rare species in the study area, i.e. were observed on just one to three palm trees with correspondingly low number of individuals (Table 1.). These species were Drynaria quercifolia, Huperzia phlegmaria, Oleandra neriiformis, and Pyrrosia longifolia. Drynaria quercifolia, which is distributed from South Asia to Australia (Hovenkamp et al. 1998), was represented by only three individuals growing on Arenga undulatifolia. H. phlegmaria, O. neriiformis, and $P$. longifolia were only found once on palm trees, viz. on Phoenix reclinata, Caryota no, and Metroxylon sagu respectively. Pyrrosia longifolia has a wide distribution, viz. from Indochina to the Pacific and Australia (Queensland); it grows in various types of forest, in disturbed or open areas and in the littoral zones, to 300 (1000) $\mathrm{m}$ sea level (Hovenkamp et al. 1998). The small plants of $P$. longifolia may be confused with $P$. lanceolata. However $P$. longifolia, as pointed by Hovenkamp et al. (1998), can be recognized by the monomorphic, very stiffleathery frond, the hicker, rigit rhizome, and the entire, short, appressed rhizome scales.

\section{The abundance of epiphytic ferns based on its ecological category}

Richards (1952), Wallace (1981) and Kress (1989) classified epiphytes into four categories, namely "true epiphytes", "hemi-epiphytes", "casual epiphytes" and in some cases "semi epiphytes climbers." True epiphytes, or holo-epiphytes, are those plants that normally spend their life cycle perched on another plant and receive all mineral nutrients from non-terrestrial sources. Hemi-epiphytes normally spend only part of their life cycle perched on another plant and thus some mineral nutrients are received from terrestrial sources. Hemi-epiphytes either begin their life cycle as epiphytes and eventually send roots and shoots to the ground (primary hemi-epiphytes), or begin as terrestrially establishes seedlings that secondary become epiphytes by severing all connections with the ground (secondary hemi-epiphytes). Species in which some individuals of a population function as true epiphytes while others are terrestrial are called casual epiphytes. Semiepiphytes climbers are vines that climb by adventitious roots which partly function in water and mineral uptake (Wallace 1981).

This study shows that habit types of the epiphytic ferns and lycophytes growing on the palm trees could be classified in to two types, true epiphytes, and casual epiphytes. Habitual holo-epiphyte or true epiphyte was the predominant ecological category, representing $75 \%$ of the species. Casual epiphyte was represented by three species only, namely Dicranopteris linearis (Burm. f.) Underw., Oleandra neriiformis Cav. and Selaginella willdenowii (Desv.) Bak. Dicranopteris linearis is actually a terrestrial fern which widely distributed throughout wetter parts of the Old World tropics and subtropics (Holttum 1959; Page 1979). This species is tolerant of shade and drought (Holttum 1938; Page 1979). The most common habitat of this fern is open-canopy sites on low-fertility soil (Holttum 1959). Oleandra neriiformis usually grows terrestrially or epiphytic, and in nature it is found in various types of forests, in open places, often making up a significant part of summit or ridge scrub, at the altitude from sea level to $2200 \mathrm{~m}$ (Hovenkamp and Ho 2012). Selaginella willdenowii (Desv.) Bak. is a terrestrial fern that usually grows as creeping, climbing, scandent, scrambling or hanging plant. In Java, it is usually found on shady slope of gorge among brushwood at about $450 \mathrm{~m}$. asl. (Setyawan et al. 2016).

\section{Species richness of epiphytic ferns growing on palm trees}

The main components of species diversity are richness and evenness. Species richness has been the subject of biodiversity studies more often than species evenness (Ma 2005). Species richness is the number of species found in a community or ecosystem. Species richness has been largely used as the only measurement of species diversity in many studies (Ricklefs and Schluter 1993; Naeem et al. 1994; Tilman 1996) as it is the single most important component of species diversity (Ma 2005). Figure 2. depict out species richness of epiphytic fern and lycopods growing on palm trees in Bogor Botanical Gardens. A host tree species may contain a diverse community of epiphytes that is often different from other host tree species (Laube and Zotz 2006). The highest total specific richness ( 8 species) was recorded on Coryota no and Arenga undulatifolia Becc ( 8 species). The lowest total species richness was found on Pinanga insignis Becc. (2 species) and Scheelea insignis (Martelli) Karsten (2 species).

While it is has been difficult to show that host specificity influences epiphyte composition (Zotz and 
Vollrath 2003) it is known that certain tree species harbor greater diversity and numbers of epiphytes (Cardelus 2002). As pointed out by Cardelus (2002), in general certain tree species phorophyte harbor greater diversity and numbers of epiphytes. There are four palm trees species that harbor greater species diversity of ferns epiphytic, namely Arenga undulatifolia, Caryota no, Attalea sp., and Attalea speciosa. These species harbor 6-8 species of ferns (Table 1, Figure 3).

\section{Host preferences of epiphytic fern species on palm trees}

Epiphyte species composition varied substantially among host species. As stated by Woods (2013), host tree identity can be an important driver of epiphyte community structure. Epiphytes usually grow and establish on tree bark and branches and in trapped soil or organic matter in crevices on bark surface or branches. Epiphyte establishment can be influenced by tree size, age, and bark texture (Callaway et al. 2002; Cardelús 2006, Zotz and Schultz 2008). One species of host tree can be a house of a diverse community of epiphytes that is often different from other host tree species' (Cardelús 2006; Laube and Zotz 2006). Host-specific differences in epiphyte assemblages suggest that epiphyte diversity may be related to variation in microhabitats within individual host trees (Cardelús and Chazdon 2005; Cardelús 2006).

Table 1. Floristic composition, types, relative frequency, and host plants of epiphytic ferns recorded growing on palm trees during the study

\begin{tabular}{|c|c|c|c|c|c|}
\hline Family and species & $\begin{array}{l}\text { Epiphytic } \\
\text { types }\end{array}$ & $\begin{array}{c}\text { Relative } \\
\text { species } \\
\text { abundance } \\
(\%)\end{array}$ & $\begin{array}{c}\text { Abundance } \\
\text { criteria }\end{array}$ & $\Sigma$ Ind. & Host plants \\
\hline \multicolumn{6}{|l|}{ Aspleniaceae } \\
\hline Asplenium nidus L. & $\mathrm{TE}$ & 3.63 & $\mathrm{C}$ & 160 & $\begin{array}{l}(1),(2),(3),(4),(5),(6),(7),(8), \\
(9),(10),(11),(12),(13),(16),(17), \\
(18),(20),(21),(22),(25),(26)\end{array}$ \\
\hline \multicolumn{6}{|l|}{ Davalliaceae } \\
\hline Davallia denticulata (Burm.) Mett. & $\mathrm{TE}$ & 10.85 & $\mathrm{C}$ & 478 & $\begin{array}{l}(2),(3),(4),(5),(6),(8),(9),(10), \\
(13),(14),(15),(16)\end{array}$ \\
\hline \multicolumn{6}{|l|}{ Gleicheniaceae } \\
\hline Dicranopteris linearis (Burm. f.) Underw. & $\mathrm{CE}$ & 0.02 & $\mathrm{R}$ & 1 & (13) \\
\hline \multicolumn{6}{|l|}{ Lycopodiaceae } \\
\hline Huperzia phlegmaria (L.) Rothm. & $\mathrm{TE}$ & 0.02 & $\mathrm{R}$ & 1 & (19) \\
\hline \multicolumn{6}{|l|}{ Nephrolepidaceae } \\
\hline Nephrolepis biserrata (Sw.) Schott & $\mathrm{TE}$ & 10.07 & $\mathrm{C}$ & 444 & $\begin{array}{l}(2),(3),(4),(5),(6),(8),(9),(10), \\
(11),(12),(13),(16),(17),(18), \\
(19),(21),(22),(24),(25)\end{array}$ \\
\hline \multicolumn{6}{|l|}{ Oleandraceae } \\
\hline Oleandra neriiformis Cav. & $\mathrm{CE}$ & 0.02 & $\mathrm{R}$ & 1 & $(16)$ \\
\hline \multicolumn{6}{|l|}{ Polypodiaceae } \\
\hline Belvisia callifolia (Christ) Copel. & TE & 7.31 & $\mathrm{C}$ & 322 & $(1),(3),(4),(6),(7),(8),(9),(17)$ \\
\hline Drynaria quercifolia (Linnaeus) J. Smith in Hooker & TE & 0.06 & $\mathrm{R}$ & 3 & (4) \\
\hline Goniophlebium percussum (Cav.) Wagner \& Grether & TE & 2.75 & $\mathrm{C}$ & 121 & (5), (13), (16), (17), (18), (19), (25) \\
\hline Microsorum punctatum (L.) Copel. & TE & 1.99 & $\mathrm{C}$ & 88 & $(4),(8),(12),(20),(22)$ \\
\hline Microsorum scolopendria (Burm. f.) Copel. & TE & 0.06 & $\mathrm{R}$ & 3 & (4) \\
\hline Pyrrosia lanceolata (L.) Farwell & TE & 2.25 & $\mathrm{C}$ & 99 & (1), (2), (5), (4), (28) \\
\hline Pyrrosia longifolia (N. L. Burman) Morton & TE & 0.02 & $\mathrm{R}$ & 1 & (8) \\
\hline Pyrrosia piloselloides (Linn.) M.G. Price & $\mathrm{TE}$ & 5.27 & $\mathrm{C}$ & 232 & $\begin{array}{l}\text { (1), (2), (4), (5), (7), (8), (11), 14), } \\
(21),(23),(26),\end{array}$ \\
\hline \multicolumn{6}{|r|}{$(21),(20),(20)$} \\
\hline Selaginella willdenowii (Desv.) Bak. & $\mathrm{CE}$ & 0.02 & $\mathrm{R}$ & 1 & (16) \\
\hline \multicolumn{6}{|l|}{ Vittariaceae } \\
\hline Vittaria ensiformis Swartz. & $\mathrm{TE}$ & 55.63 & A & 2451 & $\begin{array}{l}\text { (2), (5), (8), (13), (14), (15), (16), } \\
(17),(18),(19),(20),(22),(24)\end{array}$ \\
\hline Total 16 species; & 13 genera & 9 families & & 4406 & \\
\hline
\end{tabular}

Note: CE = Casual epiphytes; TE = True epiphytes. Abundance criteria were determined easily with the plant species that could be found growing on the palm trees. $\mathrm{A}=$ abundant; $\mathrm{C}=$ common; $\mathrm{R}=$ Rare. (1) Aiphanes minima (Gaertn.) Burret, (2) Arenga engleri Becc., (3) Arenga microcarpa Becc., (4) Arenga undulatifolia Becc., (5) Attalea sp., (6) Attalea microcarpa (H. Karst.) Linden, (7) Calypthrocalyx spicatus (Lam.) Blume, (8) Caryota no Becc., (9) Corypha umbracaulifera, (10) Corypha utan, (11). Caryota sp., (12) Corypha sp.2, (13) Elaeis guineensis Jacq., 14. Latania verschaffettii; (15)Saribus woodfordii (Ridl.) Bacon \& W.J.Baker, (16) Metroxylon sagu Rottb., (17) Attalea speciosa Mart. (18 Phoenix pusilla Gaertn.., (19) Phoenix reclinata Jacq., (20) Phoenix sp.1, (21) Phoenix sp.2, (22) Phoenix sp.3, (23) Pinanga insignis Becc., (24)Sabal palmetto (Walter) Lodd. ex Schult. \& Schult.f, (25) Sabal sp., (26) Satakentia liukiuensis (Hatus.) H.E. Moore, (27) Attalea insignis (Mart.) Drude, and (28) Verschaffeltia splendida H.A. Wendl. 


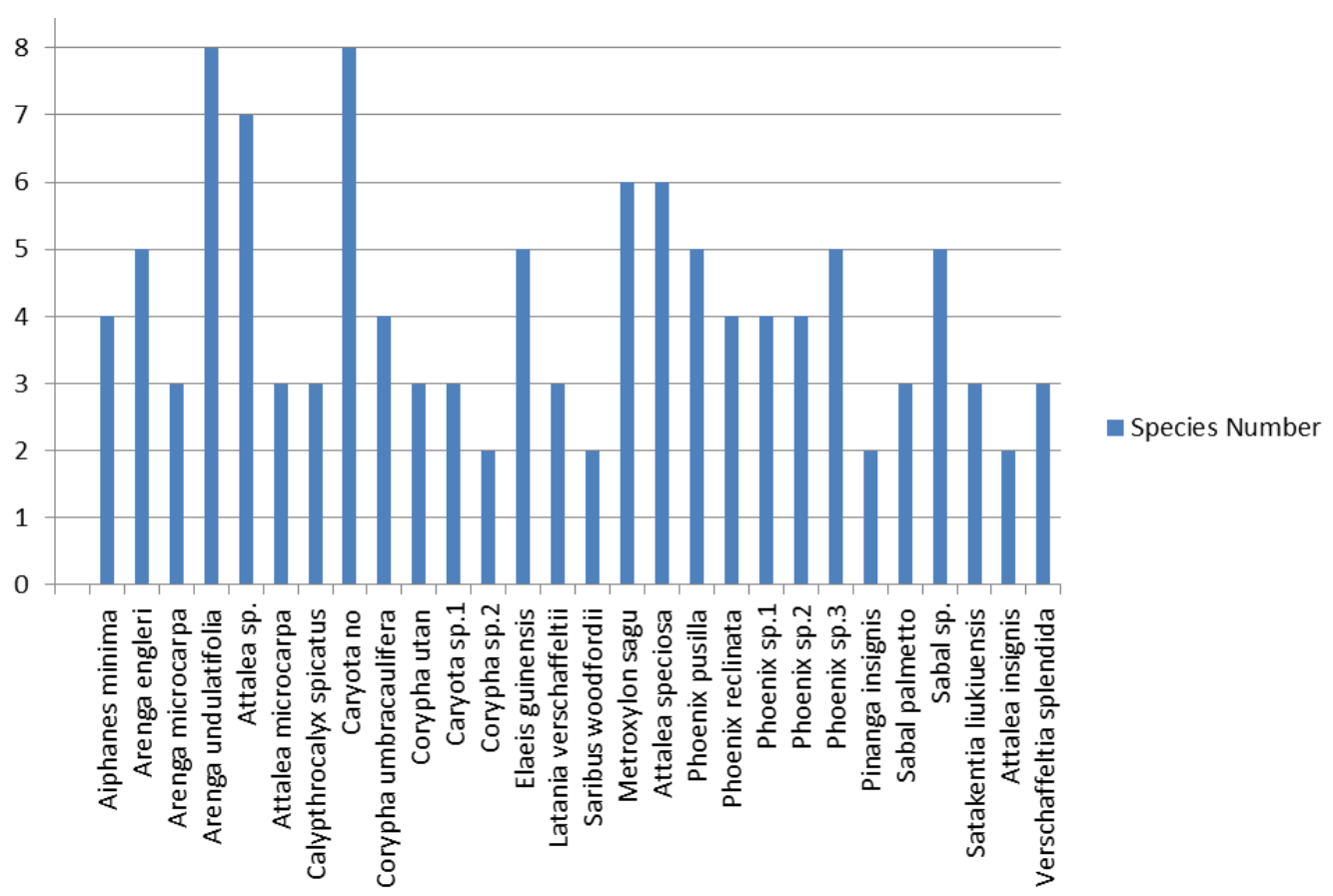

Figure 3. Number of epiphytic ferns occupied each host palm tree

The results of the analyses of the relationships between eight epiphytic species of fern and host specificity are provided in Table 2. Palm trees species do not significantly influence the individual numbers of $A$. nidus growing on. Asplenium nidus can grow and be distributed on all species of palm trees. Asplenium nidus is a common epiphytic fern of the canopy of tropical forests. Bird's nest ferns (Asplenium nidus complex) (Yatabe et al. 2009) are abundant at all heights throughout the canopy of Old World tropical forests (Fayle et al. 2009).

Palm trees species significantly influence to the individual numbers of $B$. callifolia, D. denticulata, $G$. percussum, $P$. lanceolata, $P$. piloselloides, and $V$. ensiformis. Belvisia callifolia was found to grow very well and to have high abundance on Caryota no. Pyrrosia lanceolata prefers to grow on Pinanga insignis. Palm tree species showed a significant influence on the individual number of $P$. piloselloides growing on. Pyrrosia piloselloides grow well and make thicket on the trunk of Pinanga insignis, although this species can also grow in other palm tree species, such as Arenga undulatifolia, Attalea sp., Cariota no, Phoenix sp. and Satakentia liukiuensis.

Palm species has no significant effect on the individual number of $N$. biserrata growing on. However, $N$. biserrata tends to grow abundantly on Attalea speciosa and Attalea sp. although this species also grows well in some species of palm trees such as Arenga engleri, Cariota no, Elaeis guineensis, Phoenix sp. and Attalea insignis. Oloyede et al. (2014) stated that $N$. biserrata was host-specific as most of the plants were found on the E. guineensis. However, this data proved that $N$. biserrata is not host-specific as this species can grow and make a thicked on many species of palm trees, although this species is a common epiphytic fern growing on oil palm plantation ( $E$. guineensis) (Sofiyanti 2013; Adeleye et al. 2017; Harmida et al. 2018).

Palm species showed a very significant effect on the individual number of Vittaria ensiformis growing on. Individual number of $V$. ensiformis were highest found on the stems of Sabal palmetto, although this species is also common growing on the stem of other palm species, such as Attalea sp, Elaeis guineensis, Phoenix pusilla, Metroxylon sagu and all species of Phoenix observed (5 species). However, this relation should be re-assessed as $V$. ensiformis is a general fern epiphyte, not host-specific (see Simbolon 2007). The shoestring fern (V. ensiformis) can be commonly seen on urban trees, under moderate shade. They usually thrive under the bird nest fern ( $A$. nidus) where excess rain collected will be drained down to them (Wee and Corlett 1986).

Palm tree species has significant effect on the individual number of Davallia denticulata and $G$. percussum. The first species is fond to grow on Attalea speciosa while the second species tend to grow well on the trunks of $A$. speciosa dan $P$. reclinata. The two species usually grow among the persistent leaves bases of palm trees. However, these ferns are not host-specific. In nature forest, $D$. denticulata is an epiphytic fern on many different species of trees and in different types of forest including mangrove forest or on solitary trees, epilithic on granite, limestone, or sandstone, occasionally terrestrial on different kinds of soils, e.g. on sand of kerangas forest and can be found from sea level to $2200 \mathrm{~m}$ asl. (Nooteboom 1998). G. percussum can grow terrestrially or epiphytic. In the natural forest, this species is usually found on mossy, often on rotten tree trunk of different species (Hovenkamp et al. 1998). 
Table 2. Host preference of epiphytic fern species on palm trees planted at Bogor Botanic Gardens, Indonesia (Correlation between the total individual numbers of the eight most common epiphyte species occurred and host tree taxon)

\begin{tabular}{|c|c|c|c|c|c|c|c|c|}
\hline \multirow[t]{2}{*}{ Host species } & \multicolumn{8}{|c|}{$\begin{array}{l}\text { Epiphytic fern species } \\
\text { (in code) }\end{array}$} \\
\hline & $\mathbf{A N}$ & BC & PL & $\mathbf{P P}$ & DD & NB & VE & GP \\
\hline Aiphanes minima (Gaertn.) Burret & $14 \mathrm{ab}$ & $5.33 b$ & $3.00 \mathrm{c}$ & $0.33 b$ & $0.11 \mathrm{~g}$ & - & $1.00 \mathrm{c}$ & $\mathrm{Ob}$ \\
\hline Arenga engleri Becc. & $7.33 \mathrm{ab}$ & - & $0.33 \mathrm{e}$ & $0 \mathrm{~b}$ & $11.00 \mathrm{bcd}$ & $13.33 \mathrm{ab}$ & $3.33 \mathrm{c}$ & $0 \mathrm{~b}$ \\
\hline Arenga microcarpa Becc. & $9 \mathrm{ab}$ & - & - & - & $4.33 \mathrm{defg}$ & $0.56 b$ & - & $0 \mathrm{~b}$ \\
\hline Arenga undulatifolia Becc. & $8.222 \mathrm{ab}$ & $6.44 b$ & $0.22 \mathrm{e}$ & $2.78 \mathrm{ab}$ & $15.22 \mathrm{abc}$ & $5.67 \mathrm{~b}$ & - & $0 \mathrm{~b}$ \\
\hline Attalea microcarpa Mart & $9 \mathrm{ab}$ & $7.67 \mathrm{~b}$ & $0.22 \mathrm{e}$ & - & $4.33 \mathrm{defg}$ & - & - & - \\
\hline Attalea sp. & - & $0.33 b$ & $1.67 \mathrm{~d}$ & $11.00 \mathrm{ab}$ & 8.00def & $30.33 \mathrm{a}$ & $101.00 \mathrm{~b}$ & $0.67 \mathrm{~b}$ \\
\hline Calypthrocalyx spicatus (Lam.) Blume & $6.33 \mathrm{ab}$ & $0.33 b$ & $0.22 \mathrm{e}$ & $0.33 b$ & $0.11 \mathrm{~g}$ & $0.56 \mathrm{~b}$ & - & - \\
\hline Caryota no Becc. & $35 \mathrm{a}$ & $62.33 \mathrm{a}$ & $7.33 b$ & 7.33ab & $16.00 \mathrm{ab}$ & $14.33 \mathrm{ab}$ & $1.33 \mathrm{c}$ & $0 \mathrm{~b}$ \\
\hline Elaeis guinensis Jacq. & $0.5 b$ & $0.33 b$ & $0.22 \mathrm{e}$ & - & $2.833 \mathrm{efg}$ & $12.00 \mathrm{ab}$ & $36.33 \mathrm{bc}$ & $3.33 b$ \\
\hline Latania verschaffeltii Lem. & - & $0.33 b$ & $0.22 \mathrm{e}$ & $1.00 \mathrm{~b}$ & $3.67 \mathrm{efg}$ & - & $1.00 \mathrm{c}$ & - \\
\hline Saribus woodfordii (Ridl.) Bacon \& W.J.Baker & - & $0.33 b$ & $0.22 \mathrm{e}$ & $0 b$ & $2.33 \mathrm{efg}$ & - & $77.67 \mathrm{bc}$ & $0 \mathrm{~b}$ \\
\hline Metroxylon sagu Rottb. & - & $0.33 b$ & $0.22 \mathrm{e}$ & $0 \mathrm{~b}$ & $0.11 \mathrm{~g}$ & $0.56 \mathrm{~b}$ & $27.67 \mathrm{bc}$ & $2.22 \mathrm{~b}$ \\
\hline Attalea speciosa Mart. & $0.67 \mathrm{~b}$ & $0.33 b$ & $0.22 \mathrm{e}$ & $\mathrm{Ob}$ & $20.00 \mathrm{a}$ & $31.67 \mathrm{a}$ & $25.67 \mathrm{bc}$ & $10.07 \mathrm{a}$ \\
\hline Phoenix pusilla Gaertn. & $0.5 b$ & $0.33 \mathrm{~b}$ & $0.22 \mathrm{e}$ & $\mathrm{Ob}$ & $1.00 \mathrm{fg}$ & $0.67 \mathrm{~b}$ & $15.33 \mathrm{c}$ & $1.33 b$ \\
\hline Phoenix reclinata Jacq. & - & - & - & - & $2.00 \mathrm{efg}$ & - & $26.00 \mathrm{bc}$ & $10.33 \mathrm{a}$ \\
\hline Phoenix sp.1 & $1.33 \mathrm{~b}$ & - & - & - & $3.33 \mathrm{efg}$ & - & $21.67 \mathrm{bc}$ & - \\
\hline Phoenix sp.2 & $0.33 b$ & & & $5.00 \mathrm{ab}$ & $8.67 \mathrm{cde}$ & $2.00 \mathrm{~b}$ & - & - \\
\hline Phoenix sp.3 & $1.33 \mathrm{~b}$ & - & - & - & $3.33 \mathrm{efg}$ & $12.67 \mathrm{ab}$ & $21.67 b c$ & - \\
\hline Pinanga insignis Becc. & - & - & $20.33 \mathrm{a}$ & $16.33 \mathrm{a}$ & $0.11 \mathrm{~g}$ & - & - & - \\
\hline Sabal palmetto (Walter) Lodd. ex Schult. \& Schult.f. & - & - & - & & $2.33 \mathrm{efg}$ & $1.67 \mathrm{~b}$ & $414.00 \mathrm{a}$ & - \\
\hline Satakentia liukiuensis (Hatus.) H.E. Moore & $1 b$ & - & - & $10.33 \mathrm{ab}$ & $0.33 \mathrm{~g}$ & - & - & - \\
\hline Attalea insignis (Mart.) Drude & - & - & - & - & $17 \mathrm{ab}$ & $12.67 \mathrm{ab}$ & - & - \\
\hline
\end{tabular}

Note: $\mathrm{AN}=$ Asplenium nidus $; \mathrm{BC}=$ Belvisia callifolia $; \mathrm{PL}=$ Pyrrosia lanceolata $\mathrm{PP}=$ Pyrrosia phylloseloides $;$ DD = Davallia denticulata $; \mathrm{NB}=$ Nephrolepis biserrata $; \mathrm{VE}=$ Vittaria ensiformis $; \mathrm{GP}=$ Goniophlebium percussum. The same letter in the same column shows no significantly different in 95\% Tukey's Test

Table 4. Species abundance distribution of epiphytic ferns on three zones of palm trees in Bogor Botanic Gardens, Indonesia

\begin{tabular}{lccccc}
\hline \multirow{2}{*}{ Plant zone } & \multicolumn{5}{c}{ Epiphytic ferns } \\
\cline { 2 - 6 } & Belvisia callifolia & Pyrrosia lanceolata & Davallia denticulata & Nephrolepis biserrata & Vittaria ensiformis \\
\hline Basal & $8.96 \mathrm{a}$ & $1.25 \mathrm{a}$ & $25.50 \mathrm{a}$ & $3.6 \mathrm{~b}$ & $72.54 \mathrm{a}$ \\
Middle & $1.39 \mathrm{~b}$ & $1.29 \mathrm{a}$ & $4.82 \mathrm{~b}$ & $4.46 \mathrm{~b}$ & $18.36 \mathrm{~b}$ \\
Upper & $0.68 \mathrm{~b}$ & $1.04 \mathrm{~b}$ & $1.71 \mathrm{c}$ & $10.46 \mathrm{a}$ & $1.71 \mathrm{~b}$ \\
\hline
\end{tabular}

\section{Effect of host plant zones on the species abundance of epiphytic ferns}

There were five species of epiphytic ferns that were well distributed on most species of palm trees, namely were B. callifolia, P. lanceolata, D. denticulata, N. biserrata, and $V$. ensiformis. Habitat preferences of five epiphytic fern species growing on plant zones of palm trees have been analyzed and the results are presented in Table 4 .

There were 14 palm tree species which were house for V. ensifromis, namely: Aiphanes minima, Arenga engleri, Attalea sp., Caryota no, Elaeis guineensis, Latania verschaffeltii, Saribus woodfordii, Metroxylon sagu, Attalea speciosa, Phoenix pusilla, Phoenix reclinata, Phoenix sp, Sabal palmetto, and Sabal sp. Vittaria ensiformis usually occupies the basal and middle part of stem of host palm trees where the bark of the stem is rough in texture, polish with cork and covered by the Bryophytes.
Nephrolepis biserrata tends to grow well on upper zona of trees. The situation is also occurring on $N$. biserrata growing on oil palm trees at the oil palm tree plantation. As reported by Sato et al. (1996), on tall oil palm trunks, the high frequency of $N$. biserrata is found only on upper part of the trunk. Pyrrosia lanceolata prefers the middle zone, however, its abundance value was not significantly different from those on basal zone and it was significantly different compared to the upper zona. Belvisia callifolia, D. denticulata, and V. ensiformis were found to grow well and make a dense on the basal zone of the palm trees. Vittaria ensiformis fond to grow well and make a dense on the basal zone of the palm trees. Sato et al. (1996) stated that $V$. ensiformis seems to be species of late invading ferns since they occur only trunks exceeding $4.5 \mathrm{~m}$ height.

In conclusion, a total of 16 species of epiphytic ferns included in 12 genera and eight families were recorded growing on 28 species belong to 17 genera of Arecaceae. 
Caryota no Becc. hosted the greatest number of pteridophytes (8 species) while Attalea insignis (Mart.) Drude hosted the fewest ( 2 species). The greatest richness of epiphytic fern species growing on palm trees occurred in Polypodiaceae $(50 \%)$. Nine species epiphytic ferns are common growing on the various species of palm trees, viz A. nidus, D. denticulata, N. biserrata, B. callifolia, G. percussum, M. punctatum, $P$. lanceolata, $P$. piloselloides, and $V$. ensiformis.

Palm tree species identity and tree zonation in the forest all influence species composition. Ferns and lycopods are an important component of tropical lowland epiphytic flora, therefore it is necessary that these plants be better studied and protected. The diversity of epiphytic ferns growing on palm trees clearly shows that the presence of palm trees (Arecaceae) is one of the important elements in maintaining ferns and lycopods diversity in the lowland areas.

\section{ACKNOWLEDGEMENTS}

The first author is grateful to Dr. Kartika Ning Tyas of Bogor Botanic Gardens (BBG), Indonesia for fruitful discussing to improve this manuscript. Teguh Hasto Priatmo (BBG) helped us in making herbarium specimen vouchers of the epiphytic ferns. Authors appreciate the anonymous reviewers who provided valuable suggestions for improving the manuscript.

\section{REFERENCES}

Adeleye MA, Akinsoji A, Adeonipekun PA. 2017. A survey of vascular epiphytes of oil palms (Elaeis guineensis Jacq.) in Lekk Conservation Centre, Lagos, Nigeria. FUW Trends Sci Tech J 2 (1A): 74-78.

Backer CA, Posthumus O. 1939. Varenflora voor Java. Buitenzorg, Java's Lands Plantentuin.

Bennett B. 1986. Patchiness, diversity, and abundances relationships of vascular epiphytes. Selbyana 9: 70-75.

Benzing DH. 1981. Bark surfaces and the origin and maintenance of diversity among angiosperm epiphytes: a hypothesis. Selbyana 5 : 248-255.

Benzing DH. 1984. Vascular Epiphytes: A survey with special reference to their interactions with other organisms. In: Sutton SL, Whitmore TC (eds) Tropical Rain Forest: Ecology and Management No. 2. Blackwell Scientific Publications, Oxford.

Benzing DH. 1998. Vulnerabilities of tropical forests to climate change: The significance of resident epiphytes. Clim Ch 39: 519-540.

Benzing DH. 2004. Vascular epiphytes. In: Lowman MD, Rinker HB (eds.). Forest Canopies. Second Edition. Elsevier Academic Press, London.

Brighigna L, Montini P, Favilli F, Carabez Trejo A. 1992. Role of the nitrogen-fixing bacterial microflora in the epiphytic of Tillandis (Bromeliaceae). Am J Bot 79: 723-727.

Callaway RM, Reinhart KO, Moore GW, Moore DJ, Pennings SC. 2002. Epiphyte host preferences and host traits: Mechanisms for speciesspecific interactions. Oecologia 132: 221-230.

Cardelus C. 2002. Distribution and Abundance of Vascular Epiphytes in Tropical Wet Forests. [Dissertation] University of Connecticut, Storrs, CN

Cardelús CL, Chazdon RL. 2005. Inner-crown microenvironments of two emergent tree species in a lowland wet forest. Biotropica 37 (2): 238 244. DOI: $10.1111 /$ j.1744-7429.2005.00032.x
Cardelús CL. 2006. Vascular epiphyte communities in the inner-crown of Hyeronima alchorneoides and Lecythis ampla at La Selva biological station, Costa Rica. Biotropica 39 (2): 171-176.

Christenhusz MJM, Chase MW. 2014. Trends and concepts in fern classification. Ann Bot 113: 571-594.

Coomes DA, Allen RB, Bentley WA, Burrows LE, Canham CD, Fagan L, Forsyth DM, Gaxiola-Alcantar A, Parfitt RL, Ruscoe WA, Wardle DA, Wilson DJ, Wright EF. 2005. The hare, the tortoise and the crocodile: the ecology of angiosperm dominance, conifer persistence and fern filtering. B Ecol Soc. DOI: 10.1111/j.13652745.2005.01012.x

Donald JD, Clegg JR, Ellwood MDF. 2017. Colonisation of epiphytic ferns by skinks and geckos in the high canopy of a Bornean rainforest. Herpetol Bull 141: 32-34.

Ellwood MDF, Foster WA. 2004. Doubling the estimate of invertebrate biomass in a rainforest canopy. Nature 429: 549-551.

Fayle TM, Chung AYC, Dumbrell AJ, Eggleton P, Foster WA. 2009. The effect of rain forest canopy architecture on the distribution of epiphytic ferns. Biotropica 41: 676-681.

Gentry AH, Dodson CH. 1987. Contribution of non-trees to species richness of a tropical rain forest. Biotropica 19: 149-156.

George LO, Bazzaz FA. 1999. The fern understory as an ecological filter: Emergence and establishment of canopy-tree seedlings. Ecology 80: 833-845.

Grayum MH, Churchill HW. 1987. An introduction to the Pteridophyte flora of Finca La Selva, Costa Rica. Am Fern J 77: 73-89.

Grubb PJ, Loid JR, TD Pennington TD, Whitmore TC. 1963. A comparison of mountain and lowland rainforest in Ecuador. J Ecol 51: 567-601.

Harmida, Aminasih N, Tanzerina N. 2018. Diversity of epiphytic fern on the oil palm plants (Elaeis guineensis Jacq.) in Campus of Sriwijaya University Indralaya. Biovalentia 4 (2): 1-4. [Indonesian]

Hegarty EE. 1991. Vine-host interactions. In: Putz FE, Mooney HA (eds) The Biology of Vines. Cambridge University, Cambridge.

Hietz P. 1997. Population dynamics of epiphytes in a Mexican humid montane forest. J Ecol 85: 767-775.

Hill JD, Silander JA. 2001. Distribution and dynamics of two ferns: Dennstaedtia punctilobula (Dennstaedtiaceae) and Thelypteris noveboracensis (Thelypteridaceae) in a Northeast mixed hardwoodshemlock forest. Am J Bot 88: 894-902.

Holttum RE. 1938. The ecology of tropical pteridophytes. In: Verdoon F (ed.). Manual of Pteridology. Martinus Nijhoff, The Hague.

Holttum RE. 1959. Gleicheniaceae. In: van Steenins CGGJ (ed.). Flora Malesiana, Series II, Vol. 1. Martinus Nijhoff, The Hague.

Holttum RE. 1966. A Revised Flora of Malaya. II. Ferns of Malaya. Gov Print Office, Singapore.

Hooper EA, Haufler CH. 1997. Genetic diversity and breeding system in a group of neotropical epiphytic ferns (Pleopeltis; Polypodiaceae). Am J Bot 84 (12): 1664-1674

Hovenkamp PH, Bosman MTM, Hennipman E, Nooteboom HP, RödlLinder G, Roos MC. 1998. Polypodiaceae. In: Kalkman C, Kirkup DW, Nooteboom HP, Saw LG, Stevens PF, de Wilde WJJO (eds.). Flora Malesiana, Ser. II, Ferns and Fern Allies 3. Rijksherbarium/Hortus Botanicus, Leiden.

Hovenkamp PH, Ho B-C. 2012. A revision of the fern genus Oleandra (Oleandraceae) in Asia. Phyto Keys 11: 1-37. DOI: 10.3897/phytokeys.11.2955.

Huang WS, Pike, Pike DA. 2011. Climate change impacts on fitness depend on nesting habitat in lizards. Funct Ecol 25: 1125-1136.

Köppen W. 1936. Das geographische System der Klimate. In: Köppen W, Geiger R (eds.). Handbuch der Klimatologie. Gebrüder Borntraeger, Berlin.

Kress WJ. 1986. The systematic distribution of vascular epiphytes: An update. Selbyana 9: 2-22.

Kress WJ. 1989. The systematic distribution of vascular epiphytes. In: Lüttge U (eds.). Vascular Plants as Epiphytes: Evolution and Ecophysiology. Springer-Verlag, Berlin.

Laube S, Zotz G 2006. Neither host-specific nor random: Vascular epiphytes on three tree species in a Panamanian lowland forest. Ann Bot 97: 1103-1114.

Ma M. 2005. Species richness vs evenness: independent relationship and different responses to edaphic factors. Oikos 111: 192-198.

Naeem S, Thompson LJ, Lawler SP, Lawton JH, Woodfin RM. 1994. Declining biodiversity can alter the performance of ecosystems. Nature 368: 734-737. 
Nieder J, Prosperi J, Michaloud G. 2001. Epiphytes and their contribution to canopy diversity. Plant Ecol 153: 51-63.

Nooteboom HP, Rödl-Linder G, Roos MC. 1998. Davalliaceae. In: Kalkman C, Kirkup DW, Nooteboom HP, Saw LG, Stevens PF, de Wilde WJJO (eds) Flora Malesiana, Ser. II, Ferns and Fern Allies 3. Rijksherbarium/Hortus Botanicus, Leiden.

Oloyede FA, Odiwe AI, Olujiyan AS. 2014. Composition and distribution of vascular epiphytes in different areas in Obafemi Awolowo, Nigeria. Not Sci Biol 6 (3): 316-320.

Page CN. 1979. The diversity of ferns, an ecological perspective. In: Dyer AF (ed.). The Experimental Biology of Fems. Academic Press, London.

Partomihardjo T, Kartawinata K. 1984. Epifit di Kebun Raya Bogor. Bul Kebun Raya 6 (4): 81-86. [Indonesian]

Partomihardjo T, Suzuki E, Junichi Y. 2004. Development and distribution of vascular epiphytes communities on the Krakatau Islands, Indonesia. South Pac Stud 2S (1): 7-26.

Piggott AG, Piggott JC. 1988. Ferns of Malaysia in Colour. Tropical Press, Kuala Lumpur.

Pouteau R, Meyer J-Y, Blanchard P, Nitta JH, Terorotua M, Taputuarai R. 2016. Fern species richness and abundance are indicators of climate change on high-elevation islands: Evidence from an elevational gradient on Tahiti (French Polynesia). Clim Ch. DOI: 10.1007/s10584-016-1734-x.

Prastyo WG, Heddy S, Nugroho A. 2015. Identifikasi tumbuhan paku epifit pada batang tanaman kelapa sawit (Elaeis guineensis J.) di lingkungan Universitas Brawijaya. J Prod Tan 3 (1): 65-74. [Indonesian]

Putz FE. 1983. Liana biomass and leaf area of a "Tierra Firme" forest in the Rio Negro Basin, Venezuela. Biotropica 15 (3): 185-189.

Richards PW. 1952. The Tropical Rain Forest. Cambridge University Press, London.

Ricklefs RE, Schluter D. 1993. Species diversity in ecological communities: Historical and geographical perspectives. University of Chicago Press, Chicago, IL.

Roberts NR, Dalton PJ, Jordan GJ. 2005. Epiphytic ferns and bryophytes of Tasmanian tree-ferns: A comparison of diversity and composition between two host species. Aust Ecol 30: 146-154.

Russell AE, Vitousek PM. 1997. Decomposition and potential nitrogen fixation in Dicranopteris linearis litter on Mauna Loa, Hawai'i. J Trop Ecol 13: 579-594.

Salovaara KJ, Cardenas GG, Tuomisto H. 2004. Forest classification in an Amazonian rainforest landscape using pteridophytes as indicator species. Ecography 27: 689-700.

Sanford WW. 1968. Distribution of epiphytic orchids in semi-deciduous forest in Southern Nigeria. J Ecol 56: 697-705.

Sato T, Itoh H, Kudo H, Kheong YS, Furukawa A. 1996. Species composition and structure of epiphytic fern community on oil palm trunks in Malay Archipelago. Tropics 6 (1/2): 139-148.

Scheffers BR, Phillips BL, Shoo LP. 2014. Asplenium bird's nest ferns in rainforest canopies are climate-contingent refuges for frogs. Glob Ecol Conserv 2: 37-46.

Schmitt JL, Windisch PG. 2010. Biodiversity and spatial distribution of epiphytic ferns on Alsophila setosa Kaulf. (Cyatheaceae) caudices in Rio Grande do Sul, Brazil. Braz J Biol 70 (3): 521-528.

Schneider PH, Schmitt JL. 2011. Composition, community structure and vertical distribution of epiphytic ferns on Alsophila setosa Kaulf. in Semideciduous Seasonal Forest, Morro Reuter, RS, Brazil. Acta Bot Bras 25 (3): 557-565.

Setyawan AD, Supriatna J, Darnaedi D, Rokhmatuloh, Sutarno, Sugiyarto. 2016. Diversity of Selaginella across altitudinal gradient of the tropical region. Biodiversitas 17 (1): 384-400.
Simbolon H. 2007. Epifit dan liana pada pohon di hutan pamah primer dan bekas terbakar Kalimantan Timur, Indonesia. Berita Biologi 8 (4): 249-261. [Indonesian]

Smith AR, Pryer KM, Schuettpelz E, Korall P, Schneider H, Wolf PG. 2006. A classification for extant ferns. Taxon 55: 705-731.

Smith AR, Pryer KM, Schuettpelz E, Korall P, Schneider H, Wolf PG. 2008. Fern classification. In: Ranker TA, Haufler $\mathrm{CH}$ (eds.). Biology and Evolution of Ferns and Lycophytes. Cambridge University Press, Cambridge.

Sofiyanti N. 2013. The diversity of epiphytic fern on the oil palm tree (Elaeis guineensis Jacq.) in Pekanbaru, Riau. J Biol 17 (2) : 51-55. [Indonesian]

Steenis CGGJ van 1972. The Mountain Flora of Java. EJ Brill, Leiden.

Tan KH, Akbar Z, Kunz TH. 1999. Roost selection and social organization in Cynopterus horsfieldi (Chiroptera: Pteropodidae). Malay Nat J 53: 195-298.

Tilman D. 1996. Biodiversity: population versus ecosystem stability. Ecology 77: 350-363

Veneklaas EJ, van Ek R. 1990. Rainfall interception in two tropical montane rain forests, Colomb Hydrol Process 4: 311-326.

Veneklaas EJ, Zagt RJ, van Leerdam A, van Ek, Browkhoven RAJ, van Genderen M. 1990. Hydrological properties of the epiphyte mass of a montane rain forest, Colombia. Vegetatio 89: 183-192.

Wallace BJ. 1981. The Australian Vascular Epiphytes: Flora and Ecology. [Dissertation]. University of New England, New South Wales, Australia.

Watkins JrJE, Mack MK, Mulkey SS. 2007. Gametophyte ecology and demography of epiphytic and terrestrial tropical ferns. Am J Bot 94 (4): 701-708.

Wee YC, Corlett R. 1986. The City and the Forest: Plant Life in Urban Singapore. Singapore University Press, Singapore.

Woods C. 2013. Factors Influencing the Distribution and Structure of Tropical Vascular Epiphyte Communities at Multiple Scales. [Dissertation]. Clemson University, Clemson, SC.

Yatabe Y, Shinohara W, Matsumoto S, Murakami N. 2009. Patterns of hybrid formation among cryptic species of bird-nest fern, Asplenium nidus complex (Aspleniaceae), in West Malaysia. Bot J Lin Soc 160: $42-63$.

Zapfack L, Nkongmeneck AB, Villiers JF, Lowman, M. 1996. The Importance of pteridophytes in the epiphytic flora of some phorophytes of the Cameroonian semi-deciduous rain forest. Selbyana 17: 76-81.

Zhang XC, Lu SG, YX, Qi XP, Moore S, Xing FW, Wang FG, Hovenkamp PH, Gilbert MG, Nooteboom HP, Parris BS, Haufler C, Kato M, Smith AR. 2013. Polypodiaceae. In: WuY, Raven PH, Hong DY (eds.). Flora of China Vol. 2-3 (Pteridophytes). Science Press, Beijing \& Missouri Botanical Garden Press, St. Louis.

Zotz G, Bader M. 2009. Epiphytes in a changing world: Global change effects on vascular and non-vascular epiphytes. Prog Bot 70: 47-70.

Zotz G, Büche M. 2000. The epiphytic filmy ferns of a tropical lowland forest-species occurrence and habitat preferences. Ecotropica 6: 203206.

Zotz G, Hietz P. 2001. The physiological ecology of vascular epiphytes: Current knowledge, open questions. J Exp Bot 52 (364): 2067-2078

Zotz G, Schultz S, 2008. The vascular epiphytes of a lowland forest in Panama-species composition and spatial structure. Plant Ecol 195: 131-141.

Zotz G, Volrath B. 2003. The epiphyte vegetation of the palm Socratea exorrhiza correlations with tree size, tree age and bryophyte cover. $\mathrm{J}$ Trop Ecol 19: 81-90. 